\title{
Türkçe Öğretmeni Adaylarının Okumaya ve Okuma Eğitimine İlişkin Özyeterlik Algıları
}

Mehmet KURUDAYIOĞLU* Gamze ÇELIK***

\section{Özet}

$\mathrm{Bu}$ çalışmada okuma alışkanlığını gençlere kazandıracak olan öğretmen adaylarının, okumaya ve okuma eğitimine ilişkin özyeterlik algıları tespit edilmeye çalışılmıştır. Araştırma betimsel niteliktedir. Çalışmada tarama modeli kullanılmıştır ve anket uygulanmıştır. Çalışma grubunu, 2010-2011 akademik yılında, Çanakkale Onsekiz Mart Üniversitesi Eğitim Fakültesi Türkçe Eğitimi Bölümü'nde 3. ve 4. sinıfta öğrenim gören 156 öğretmen adayı oluşturmaktadır. Çalışma bahar döneminde 2011 MayısHaziran ayları arasında gerçekleştirilmiştir. Verilerin çözümlenmesinde ortalama, yüzde, frekans, T-testi ve tek yönlü varyans analizi (ANOVA) istatistiksel yöntemleri kullanılmıştır.

Anket sonuçlarına göre öğretmen adayları; "Kitap okumanın yararlı olduğunu düşünüyorum." konusunda kendilerini yeterli görmektedir. "Okuma alışkanlığını kazanmanın önemi konusunda duyarlı olma", "okuduklarındaki öznel ve nesnel yargıları ayırt edebilme" konularında kendilerini kısmen yeterli görmektedirler. Türkçe Öğretmeni adaylarının cinsiyete göre okuma eğitimi algıları arasında anlamlı bir farklılık yoktur. Aynı şekilde okuma yeterliği ile cinsiyetleri arasında anlamlı bir farklılık yoktur. Sınıf düzeyine bağlı olarak Türkçe öğretmeni adaylarının okuma becerisi özyeterliği algılarında anlamlı bir farklılık görülmüştür. Öğretim şekli ile okuma eğitimi ve okuma becerisi özyeterlik algıları arasında da anlamlı bir ilişki vardır. Son olarak; öğretmen adaylarının mezun oldukları lise türleri ile okuma becerisi ve okuma eğitimi özyeterlik algıları arasında anlamlı bir ilişki görülmemiştir.

Anahtar Kelimeler: okuma, Türkçe eğitimi, özyeterlik, okuma eğitimi, Türkçe öğretmeni.

\section{Pre-Service Turkish Language Teachers' Self Sufficient on Reading and Reading Education}

\footnotetext{
* Doç.Dr. Çanakkale Onsekiz Mart Üniversitesi, Eğitim Fakültesi, Türkçe Eğitimi, mkurudayi@hotmail.com

Arş.Gör. Çanakkale Onsekiz Mart Üniversitesi, Eğitim Fakültesi, Türk Dili ve Edebiyatı Eğitimi, gamzecelik@gmail.com
} 


\begin{abstract}
In this study, it is aimed to reveal pre-service Turkish Language teachers' perceptions about reading and reading education. This study is descriptive in nature. To collect data, a questionnaire developed by researchers was used and the data analyzed by survey method. 156 preservice Turkish Language Teachers who were taught in $3^{\text {rd }}$ and $4^{\text {th }}$ grade participated. The questionnaire was applied to participants in 2011, spring term. Mean, percent, frequencies, t-test, one-way ANOVA statistical procedures were used to acquire the results.

According to results, all pre-service teachers believed that "reading books are beneficial". On the other hand, they found themselves partly adequate about "To be sensitive for importance of gaining reading habit" and "to be aware of objective and subjective notions". There is no statistical difference between men and women pre-service teachers' preconceptions about reading education and reading proficiency. It is understood from statistical analysis that $4^{\text {th }}$ grade pre-service teachers found themselves more adequate than $3^{\text {rd }}$ grade pre-service teachers. Additionally, pre-service teachers who were taught in evening education found themselves more adequate than the others in formal education. Finally, there is no statistical difference about pre-service teachers' perceptions reading proficiency and reading education as to high schools which they graduated
\end{abstract}

Key Words: reading, Turkish education, sufficient, reading education, Turkish language teacher.

\title{
Giriş
}

Okuma eylemi insanlara farklı dünyaların kapılarını açmaktadır. Bireyin kendisini geliştirmesine ve bireyin kendisine ve çevresine karşı farkındalık oluşturmasına yardımcı olmaktadır. Ancak okuma alışkanlığı uzun bir sürecin sonunda kazanilan bir beceridir. Bu sebeple erken yaşlardan itibaren bireylere okuma alışkanlığı kazandırılmadığı takdirde ileriki yaşlarda bu becerinin kazanılması güç olmaktadır.

Okuma kavramının farklı tanımları yapılmıştır. Okuma; "Ses organları ve göz yoluyla algılanan işaret ve sembollerin beyin tarafından yorumlanarak değerlendirilmesi ve anlamlandırılması sürecidir." (MEB, 
2006). Arıcı'ya (2008) göre okuma; gözlerin ve ses organlarının farklı hareketlerinden ve zihnin anlamı kavramak için verdiği çabadan meydana gelen bir etkinliktir. Bamberger'e okuma; "Aklın gelişmesine kendi başına büyük katkı yapan çok düzeyli zihinsel bir süreçtir." Staiger'in (aktaran Kurulgan ve Çekererol, 2008) yaptığ1 tanıma göre ise okuma; "Bir yazar tarafından görsel uyarıcı şeklinde kodlanan anlamın, okuyucunun aklında da bir anlam ifade etmesi şeklinde gerçekleşen bir etkileşimi anlatan terimdir.".

“Okuma yazma; bireyde bilgiyi, bilimi, demokratik bakış açısını, özgür ve yaratıcı düşünceyi geliştirici; toplumu çağdaş evrensel değerler çerçevesinde biçimlendirici ve her türlü üretimi sağlayıcı toplumsal bir olgudur (Yılmaz, 2006). Ulusal ve evrensel kültürü oluşturan tüm kazanım ve değerler, ancak okumakla mümkündür.

Aytaş (2005)'a göre; okuma bir metnin gözle takip edilmesi ve beyin tarafından algılanması olarak tanımlanırken, kimilerine göre de özel bir eğitimle kazanılabilecek bir beceridir. Okuma bir zorunluluk olduğundan anlamını kaybetmektedir. Birey okumayı kendisi için temel bir ihtiyaç olarak gördüğü zaman okumanın süreklilik gösterdiği görülmektedir. Okuma salt kelimelerin birbirine bağlandığ 1 kolay bir birleştirme işleminden ibaret olarak düşünülmemelidir. Sembolleri görmek yeterli değildir. Bu sembolleri anlamak, yorumlamak, karşılaştırmak, akıl yürütmek ve bunların sonucunda bir yargiya ulaşmak da gerekmektedir (Özbay ve Özdemir, 2012).

Akyol (2012) iyi okuyucunun okuduğundan anlam kurma beklentisiyle metinle karşı karşıya geldiğini belirtmiştir. Metne çabukça göz gezdiren okuyucu, materyalin türünü belirlemekte ve materyali ne amaçla okuduğunun bilincinde olmaktadır. Okuma ortamına konuyla ilgili ön bilgilerini aktarmakta, böylece okuyucu tahmin yaparken de zorlanmamaktadır. İyi bir okuyucu, okuma anında anlama durumunu sürekli kendi kendine kontrol etmektedir. Karmaşık ifadeleri açılığa kavuşturmaktadır. Anlaşılamayan bölümü tekrar okuyarak veya öğretmeninden yardım alarak gerektiği zamanlarda yardımcı stratejileri kullanmaktadır. İyi bir okuyucu okumanın ardından okuduklarına eleştirel gözle bakmakta ve okuduklarını uygun bir şekilde özetleyerek metni değerlendirmektedir. 
Okumak bireyi sorgulamaya yönlendirdiği zaman hedefine ulaşmış olacaktır. Her bilgiyi kabul etmek ve o bilginin tek doğru olduğunu varsaymak iyi bir okuyucu için geçerli değildir. Okuduklarını eski bilgileriyle kıyaslamak ve kendi doğrularıla harmanlayarak bir felsefe oluşturmak bireyi geliştirir. Kitap okuma alışkanlığı bu nedenle kolay kazanılan bir alışkanlık değil, zamanla gelişen bir beceridir.

Daha önceki dönemlerde "Okumak anlamaktır" anlayışı hakimken, günümüzde "öğrenmek için okuma" anlayışına ağırlık verilmiştir. Sadece okunan metinle yetinmemek gerekmektedir. Okuyucu metinden elde ettiği bilgileri sorgulamalı ve genişletmelidir. Okuyarak elde ettiği bilgilerden yararlanmak için tüm bu bilgileri sistemli hale getirmelidir (Güneş, 2012).

Günümüzde teknoloji alanında görülmekte olan hızlı gelişmeler bilginin üretilmesini, aktarılmasını, algılayıp yorumlanmasını daha önemli duruma getirmiştir. Bu anlamda, bilginin kaynakları da eskisine göre zenginleşmiştir. Değişmeyen iki temel zorunluluk ise; bilginin yazılı ve görsel olarak sunulması ve sunulan bu bilginin okunması, anlaşılması ve değerlendirilmesidir. Buna göre okuma eylemi; insanın var oluşundan beri bilgiyi elde etmenin en önemli yollarından birisi olmuştur. Gelecekte de aynı durum geçerli olacaktır (Temizkan, 2009).

Kitap okuma kişinin kendisini geliştirmesini, ana dilini güzel kullanabilmesini sağlamaktadır. Kendimizi doğru ifade edebilmemiz için iyi bir okuyucu olmamız önem taşımaktadır. Kitle iletişim araçlarının yaygınlık kazanmasıyla ve teknolojinin hızla gelişmesiyle birlikte insanoğlu artık bilgiye kolayca ulaşabilmektedir. Ancak kitaplar bilgiye ulaşmada günümüzde de vazgeçilmez kaynaklar arasındadır. Kitap okumanın insana verdiği duyguyu, teknolojinin getirdiği yeniliklerle bulmak mümkün değildir.

Kitap okumanın sırrı asırlar boyunca çözülebilmiş değildir. Okumanın nasıl gerçekleştiği merak edilen ve derin tefekkür gerektiren bir konudur. Manguel (2004), kitap okumanın gizemlerini keşfetmeye çalışırken, aslında okuma yeteneğinin içimizde doğuştan var olduğunu bizim bunu istediğimizde ve zamanı geldiğinde ortaya çıkardığımızı savunmuştur. Bu durum Platoncu düşünceye kadar bizi götürmektedir. Nitekim Platoncu görüşte de bir şeyi görmeden önce onun düşüncesinin zaten bizde var olduğu kabul edilir. Tüm bunlar belki de bizim için bir armağandır (Manguel, 2004). 
Metinden anlam çıarma, metindeki düşünceleri yorumlayabilme okuyucunun zihinsel ve fiziksel özelliklerine bağlıdır. Okuma sürecinde metin sadece bir uyarıcı görevindedir. Asıl amaç ise; alfabeler halinde kodlanarak iletilen mesajın okuyan insanın beyninde anlam bulmasıdır (Kurudayıoğlu, 2011).

Gömleksiz (2004)'e göre; öğrencilere kitaplardaki bilgileri ezberletmek, onlardan kitaplarda anlatılanları yorum yapmadan eleştirmeden öğrenmelerini istemek öğrencilerin kitaplardan soğumalarına neden olmaktadır. Böyle uygulamalar yerine gençleri kendi ilgi alanlarındaki kitapları okumaya yönlendirmek, araştırma ve inceleme yapmalarını, tartışmalarını ve not almalarını sağlamak onlarda okuma ilgisi uyandırabilecektir.

Okuma alışkanlığının kazanılmaması sonucunda basılan kitap sayısında da azalma gözlenmektedir. Avrupa ülkeleriyle yıllık kitap basımı karşılaştırıldığ1 zaman Türkiye'de 6031, Almanya'da 65000, İngiltere'de 48000, İtalya'da 17000, Yugoslavya'da 10000 olduğu görülmektedir. (Filiz, 2004). Ülkemizde okuma oranının yüksek olmaması okuma alışkanlığının yerleşmemiş olmasından kaynaklanmaktadır. Bu konuda yapılan araştırmalar ülkemizde kitap okumaya yeterince vakit ayrılmadığını göstermektedir. Kütüphanelerden yararlanma oranının da yeterli düzeyde olmadığı araştırmalar sonucunda tespit edilmiştir. Şahin (2010)'in yaptı̆̆ 1 çalışmanın sonuçlarına göre; Türkçe öğretmeni adayları kütüphaneleri genel olarak araştırma yapmak ve ders çalışmak için kullanmaktadırlar. Öğretmen adaylarının "ihtiyaçları oldukça" veya "ayda bir" ödünç kitap aldıkları belirlenmiştir. Oysa kütüphanelere daha sık gidilmesi ve kitap okumaya daha fazla zaman ayrılması gerekmektedir.

Avrupa ülkelerine baktığımız zaman pek çok Aile Okuryazarlık Programları ailelerin çocuklarına yüksek sesle okuma yapmaları için tavsiyede bulunmaktadır. Bununla ilgili eğitim de verilmektedir. Ancak araştırmalar bunun yeterli olmadığını göstermektedir. Etkili okuryazarlık programları ebeveynlere çocuklarına belirli okuryazarlık becerilerini nasıl öğretmeleri gerektiği konusunda da eğitim vermelidir (Avrupa Komisyonu, 2011).

Okuma alışkanlığının kazandırılmasında yetişkinlerin gençlere örnek olması etkili olmaktadır. Anne ve babasının okuduğunu ve bunu bir yaşam biçimi haline getirdiğini gören gençler de okumaya ilgi 
duyacaklardır. Öğretmenler ise gençlere okuma alışkanlığı kazanma konusunda rehber olmalıdır. Türkçe öğretmenleri okuma sevgisinin kazandırılması konusunda diğer öğretmenlere göre daha çok etkili olabilmektedir. Ancak elbette okuma konusunda sadece Türkçe öğretmenleri değil, tüm öğretmenlerin öğrencilerine yol gösterici olması gerekmektedir.

Karatay (2011:240)'a göre; okullarda her yaş düzeyi için “Okuma Kulüpleri" kurulmalı ve bunların yapacağı çalışmalar hakkında ailelere ve öğretmenlere dönüt verilmelidir. Konuşulmayan, gündemde tutulmayan bir durumun alışkanlık olarak kazanılması mümkün değildir. Okuma alışkanlığının gençlere kazandırılmasında sadece öğretmenlerin ve ailelerin model olması yetmeyecektir. Sanatçıların, sporcuların, devlet adamlarının da iyi birer model olması faydalı olacaktır.

Aytaş (2005) okuma alışkanlığının kazandırılması için, hoşa gidecek ve ilgi çekecek bir okuma ortamı oluşturulması gerektiğine dikkat çekmektedir. Okuma alışkanlığı bir seferde değil, uzun sürede kazanılabilecek bir alışkanlıktır. Ancak bir defa kazanılırsa, hayatın olmazsa olmazları arasına karışan ve vazgeçilemeyen bir özelliğe dönüşmektedir. Bunun için de gerçekten etkili olacak bir okuma eğitimi sürecine ihtiyaç vardır. Öğrencinin eline okuması için kitabı tutuşturmak mesele değil, önemli olan onların iyi bir okuyucu olmaları için gereken birikime, sabır ve enerjiye sahip olmalarını sağlamaktır. $\mathrm{Bu}$ da okuma alışkanlığının kazanılmasıyla mümkündür.

Avrupa Komisyonu tarafından hazırlanan Uluslararası Öğrenci Başarı Araştırmalarına göre okuma performansı üzerinde etkisi olan faktörler üç seviyede incelenmektedir:

1. Öğrenci ve ailelerinin özellikleri,

2. Öğretmen ve okulların taşıdığı özellikler,

3. Eğitim sistemlerinin özellikleri. Okuma performansını bu sayılan özellikler doğrudan etkilemez. Ancak müdahale edilme şansı bulunduğundan bu tür etkiler hakkında bilgi sahibi olmak gerekmektedir (Avrupa Komisyonu, 2011).

Ünlü Alman yazarı Goethe'nin bir özdeyişi şöyledir: “Okumayı öğrenmek sanatların en gücüdür. Ben bu işe yaşamımın seksen yılını verdim yine de tam olarak öğrendiğimi söyleyemem." Yazarın bu sözü okumanın 
çok değişik boyutlarının olduğunun göstergesidir. Akşit Göktürk; “Oku da adam ol!", "Çok okuyan çok bilir." gibi okuma eyleminin dilimizde farklı anlamları çağrıştırdığına dikkat çekmektedir (Temizkan, 2009).

$\mathrm{Bu}$ çalışmada öğretmen adaylarının okuma becerisi üzerindeki yeterlilikleri iki boyutlu olarak incelenmiştir. Araştırmanın birinci boyutunu öğretmen adaylarının okuma becerisi özyeterlik algıları oluştururken, ikinci boyutunu ise okuma eğitimi özyeterlik algıları oluşturmaktadır. Literatürde özyeterliğin tanımına bakıldığında; bireyin kendi yeteneklerine inanarak hayatını etkileyecek olaylarda performans sergilemesi olarak açılandığ 1 görülmektedir. İnsanların nasıl hissettiğini, nasıl düşündüğünü, kendilerini nasıl motive ettiklerini ve nasıl davranışlar sergilediklerini "özyeterlik algısı" açıklamaktadır. Özyeterlik algısının bilişsel, güdüsel, duyuşsal ve seçim süreçleri üzerinde etkileri olduğu bilinmektedir (Çetin, 2008). Bandura (2006) özyeterliği; insanların başarı üretmelerine olan inançlarına duydukları ilgi olarak tanımlamıştır. İnsanlar farklı alanlarda kendilerini geliştirmek için mücadele vermektedir. Kişisel duygular çeşitli alanlarda bireysel yeterlilikleri etkilemektedir. Belirli bir konuda kendini değerlendirebilmek, kişinin kendi eksiklerini görebilmesini sağlamaktadır. Böylece kişi bu eksikleri tamamlamaya çalışabilecek ve becerilerini geliştirmek için gerek teorik gerek uygulama olarak gereken çabayı göstermek için yola çıkacaktır. Çalışmamızda okuma eğitimi konusunda öğretmen adaylarının kendilerini değerlendirmelerini istememizin altındaki amaç da burada ortaya çıkmaktadır.

\section{Araştırmanın Amacı}

Araştırmanın temel amacı; Türkçe öğretmeni adaylarının okuma ve okuma eğitimi konusundaki yeterlilik düzeylerine ilişkin algılarını belirleyebilmektir. Bu temel amaca bağlı olarak belirlenen alt amaçlar ise; Türkçe öğretmeni adaylarının;

1. Cinsiyetleri ile okuma ve okuma eğitimi özyeterlik algıları arasında bir ilişki var mıdır?

2. Sınıf düzeyleri ile okuma ve okuma eğitimi özyeterlik algıları arasında bir ilişki var mıdır?

3. Öğretim şekli ile okuma ve okuma eğitimi özyeterlik algıları arasında bir ilişki var mıdır? 
4. Mezun oldukları lise ile okuma ve okuma eğitimi özyeterlik algıları arasında bir ilişki var mıdır?

\section{Yöntem}

\section{Araştırmanın Modeli}

Bu çalışma betimsel nitelikte bir araştırmadır. Çalışmada tarama modeli kullanılmıştır. Karasar'a (2007) göre; bu tür çalışmalarda var olan durum değiştirilmeden aktarılmaktadır. Araştırmacı bilinmek isteneni uygun yollarla tespit eder, gözlemler ve ortaya çıkarır.

\section{Çalışma Grubu}

Araştırmanın çalışma grubunu, 2010-2011 akademik yılında, Çanakkale Onsekiz Mart Üniversitesi Eğitim Fakültesi Türkçe Eğitimi Bölümü'nde 3. ve 4. sinıfta öğrenim gören 156 öğretmen adayından oluşmaktadır. Çalışma bahar döneminde 2011 Mayıs-Haziran ayları arasında gerçekleştirilmiştir.

Tablo 1: Türkçe Öğretmeni Adaylarının Kişisel Özellikleri

\begin{tabular}{lll}
\hline Özellik & F & $\mathbf{\%}$ \\
\hline Cinsiyet & & \\
Erkek & 71 & 45,5 \\
Kadın & 85 & 54,5 \\
TOPLAM & $\mathbf{1 5 6}$ & $\mathbf{1 0 0}$ \\
\hline Mezun olduğu lise türü & & \\
Genel Lise & 57 & 36,5 \\
Yabancı Dil Ağırlıklı Lise & 34 & 21,8 \\
Anadolu Lisesi & 40 & 25,6 \\
Anadolu Öğretmen Lisesi & 23 & 14,7 \\
Diğer & 2 & 1,3 \\
TOPLAM & $\mathbf{1 5 6}$ & $\mathbf{1 0 0}$ \\
\hline Öğretim Şekli & & \\
Normal Öğretim & 79 & 50,6 \\
İkinci Öğretim & 76 & 48,7 \\
TOPLAM & 156 & 100 \\
\hline Sınıf düzeyi & & \\
3. Sınıf & 106 & 67,9
\end{tabular}




\begin{tabular}{lll} 
4. Sinif & 50 & 32,1 \\
TOPLAM & $\mathbf{1 5 6}$ & $\mathbf{1 0 0}$ \\
\hline Not ortalamas1 & & \\
$1,51-2,00$ & 2 & 1,3 \\
$2,01-2,50$ & 30 & 19,2 \\
$2,51-3,00$ & 73 & 46,8 \\
$3,01-3,50$ & 49 & 31,4 \\
$3,51-4,00$ & 2 & 1,3 \\
TOPLAM & $\mathbf{1 5 6}$ & $\mathbf{1 0 0}$ \\
\hline
\end{tabular}

Tablo 1 incelendiğinde; araştırmaya katılan öğretmen adaylarının 71'i (\% 45,5) erkek, 85'i (\% 54,5) kadındır. Mezun olduğu lise türüne bakıldığında öğretmen adaylarının 57'si $(\%$ 36,5) Genel Lise, 34'ü (\% 21,8) Yabancı Dil Ağırlıklı Lise, 40’ı (\% 25,6) Anadolu Lisesi, 23'ü (\% 14,7)'si Anadolu Öğretmen Lisesi mezunudur. Öğretmen adaylarının devam ettikleri öğretim şekline göre ise $79^{\prime} u(\%$ 50,6) normal öğretimde okurken, 76 'sı (\% 48,7) ikinci öğretimde okumaktadır. Öğretmen adaylarının 106's1 (\% $67,9)$ 3. sinıfa devam etmektedir. 50'si (\% 32,1) 4. sinıf öğrencisidir. Öğretmen adaylarının not ortalamalarına bakıldığında; 2 'si (\% 1,3) 1,51-2,00, 30 'u (\% 19,2) 2,01-2,50, 73'ü (\% 46,8) 2,51-3,00, 49'u (\% 31,4) 3,01-3,50 ve 2'si $(\%$ 1,3),3,51-4,00 ortalamalar arasında not ortalamasına sahiptir.

\section{Verilerin Toplama Araçları}

Öğretmen adaylarının okuma ve okuma eğitimi özyeterlilik algılarını tespit etmek amacıyla araştırmacılar tarafından anket geliştirilmiştir. Anket maddeleri Türkçe Dersi Öğretim Programı'nda (MEB, 2006) okuma becerisi kazanımlarından yararlanılarak ve ilgili literatür taranarak oluşturulmuştur. Daha sonra uzman görüşleri alınmıştır. Anketin güvenirliği , 932 olarak ölçülmüştür ve bu değer ölçeğin güvenilir olduğunu ifade etmektedir.

Anket üç bölümden oluşmaktadır. Birinci bölümde; kişisel bilgilere yer verilmiştir. İkinci bölümde; okuma eğitimi algılarına ilişkin özyeterlilik maddeleri bulunmaktadır. Üçüncü bölümde; okuma becerisi özyeterlilik maddeleri ise son bölümün sorularını oluşturmuştur.

“Okuma Becerisi Özyeterlilik" ölçeğinden elde edilen veriler, SPSS paket programı aracılığıyla frekans, yüzde, ortalama, standart sapma, bağımsız gruplar (ilişkisiz örneklem) T-testi ve ANOVA istatistik teknikleri 
kullanılarak analiz edilmiş ve yorumlanmıştır. Ölçekte her bir maddeden verilen cevaplar "kesinlikle katılıyorum=5", "katıliyorum=4", "kararsızım=3", "katılmıorum=2", kesinlikle katılmıyorum=1" şeklinde puanlanmıştır. Veriler girildikten sonra olumsuz maddelerdeki puanlar "kesinlikle katıliyorum=1", "katılıyorum=2", "kararsızım=3", "katılmıyorum=4", "kesinlikle katılmıorum=5" olarak değiştirilmiştir.

\section{Bulgular ve Yorum}

Araştırmanın bu bölümünde çalışmanın sonucunda ulaşılan bulgulara ve bunlara ilişkin yorumlara yer verilmiştir. Türkçe öğretmeni adaylarının okuma becerisi özyeterlik algılarıyla ilgili bulgular ve araştırmanın alt amaçları sırasıyla ele alınmıştır. Sonuçlar tablolarla gösterilmiş ve literatürle karşılaştırılarak yorumlanmıştır.

Tablo 2. Türkçe Öğretmeni Adaylarının Okuma Becerisi Özyeterlik Algıları

\begin{tabular}{|c|c|c|c|c|c|c|c|c|c|c|c|c|}
\hline & \multicolumn{2}{|c|}{ 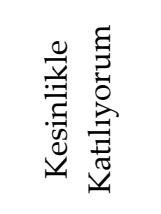 } & \multicolumn{2}{|c|}{ 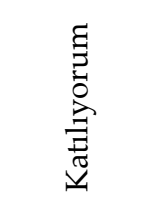 } & \multicolumn{2}{|c|}{ 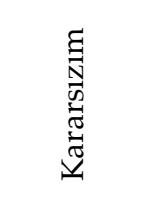 } & \multicolumn{2}{|c|}{ 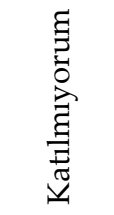 } & \multicolumn{2}{|c|}{ 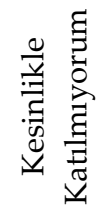 } & \multirow[t]{2}{*}{$\bar{X}$} & \multirow[t]{2}{*}{$S$} \\
\hline & $\mathrm{f}$ & $\%$ & $\mathbf{f}$ & $\%$ & f & $\%$ & $\mathbf{f}$ & $\%$ & $\mathbf{f}$ & $\%$ & & \\
\hline $\begin{array}{l}\text { 1. Okuma } \\
\text { alışkanlığını } \\
\text { kazanmanın önemi } \\
\text { konusunda } \\
\text { duyarlıyım. }\end{array}$ & 73 & 46.8 & 70 & 44.9 & 12 & 7.7 & 1 & .6 & - & - & 4.37 & .65 \\
\hline $\begin{array}{l}\text { 2. Kitap okumanın } \\
\text { yararlı olduğunu } \\
\text { düşünüyorum. }\end{array}$ & 112 & 71.8 & 41 & 26.3 & 3 & 1.9 & - & - & - & - & 4.69 & .50 \\
\hline $\begin{array}{l}\text { 3. Okuma türleri } \\
\text { konusunda yeterli } \\
\text { bilgiye sahibim. } \\
\end{array}$ & 45 & 28.8 & 85 & 54.5 & 21 & 13.5 & 5 & 3.2 & - & - & 4.08 & .73 \\
\hline $\begin{array}{l}\text { 4. Kitap okumanın } \\
\text { zaman kaybı } \\
\text { olduğunu } \\
\text { düşünüyorum. }\end{array}$ & 119 & 76.3 & 33 & 21.2 & 4 & 2.6 & - & - & - & - & 4.73 & .49 \\
\hline $\begin{array}{l}5 . \text { Okuma } \\
\text { becerisinin eğitimle } \\
\text { kazandırılabileceğini }\end{array}$ & 60 & 38.5 & 79 & 50.6 & 14 & 9.0 & - & - & 3 & 1.9 & 4.23 & .77 \\
\hline
\end{tabular}


Uşak Üniversitesi Sosyal Bilimler Dergisi

$2013,6 / 4$

M. KURUDAYIOĞLU, G. ÇELIKK

\begin{tabular}{|c|c|c|c|c|c|c|c|c|c|c|c|c|}
\hline düşüni & & & & & & & & & & & & \\
\hline $\begin{array}{l}\text { 6. Okuduğum } \\
\text { metinlerin türünü } \\
\text { belirleyebilirim. }\end{array}$ & 70 & 44.9 & 81 & 51.9 & 5 & 3.2 & - & - & . & - & 4.41 & .55 \\
\hline $\begin{array}{l}\text { 7. Okuduklarımdan } \\
\text { çıkarımlar } \\
\text { yapabilirim. }\end{array}$ & 80 & 51.3 & 70 & 44.9 & 5 & 3.2 & 1 & .6 & . & - & 4.46 & .59 \\
\hline $\begin{array}{l}\text { 8. İyi bir okur } \\
\text { olduğumu } \\
\text { düşünüyorum. }\end{array}$ & 45 & 28.8 & 74 & 47.4 & 27 & 17.3 & 8 & 5.1 & 2 & 1.3 & 3.97 & .88 \\
\hline $\begin{array}{l}\text { 9. Okuduklarımdaki } \\
\text { öznel ve nesnel } \\
\text { yargıları ayırt } \\
\text { edebilirim. }\end{array}$ & 68 & 43.6 & 77 & 49.4 & 10 & 6.4 & 1 & .6 & - & - & 4.35 & .63 \\
\hline $\begin{array}{l}\text { 10. Metne göre } \\
\text { okuma türü } \\
\text { belirleyebilirim. }\end{array}$ & 54 & 34.6 & 79 & 50.6 & 23 & 14.7 & - & - & - & - & 4.19 & .67 \\
\hline $\begin{array}{l}\text { 11. Amacıma göre } \\
\text { okuma metni } \\
\text { seçebilirim. }\end{array}$ & 63 & 40.4 & 83 & 53.2 & 10 & 6.4 & - & - & - & - & 4.33 & .59 \\
\hline $\begin{array}{l}\text { 12. Türüne göre } \\
\text { okuma metni } \\
\text { seçebilirim. }\end{array}$ & 78 & 50.0 & 66 & 42.3 & 11 & 7.1 & 1 & .6 & - & - & 4.41 & .65 \\
\hline $\begin{array}{l}\text { 13. Farklı yazarların } \\
\text { kitaplarını okumaya } \\
\text { çalışırım. }\end{array}$ & 65 & 41.7 & 72 & 46.2 & 12 & 7.7 & 7 & 4.5 & - & - & 4.25 & .78 \\
\hline $\begin{array}{l}\text { 14. Okuma } \\
\text { kurallarını } \\
\text { uyguları. }\end{array}$ & 51 & 32.7 & 80 & 51.3 & 21 & 13.5 & 1 & .6 & 3 & 1.9 & 4.12 & .80 \\
\hline $\begin{array}{l}\text { 15. Okuma becerimi } \\
\text { geliştirerek söz } \\
\text { varlığımı } \\
\text { zenginleştiririm. }\end{array}$ & 54 & 34.6 & 88 & 56.4 & 10 & 6.4 & 4 & 2.6 & - & - & 4.23 & .68 \\
\hline $\begin{array}{l}\text { 16. Okuduğum } \\
\text { metinleri dil ve } \\
\text { anlatım yönünden } \\
\text { değerlendiririm. } \\
\end{array}$ & 51 & 32.7 & 90 & 57.7 & 15 & 9.6 & - & - & - & - & 4.23 & .61 \\
\hline $\begin{array}{l}\text { 17. Okuduğum } \\
\text { metinleri içerik } \\
\text { yönünden } \\
\text { değerlendiririm. }\end{array}$ & 58 & 37.2 & 90 & 57.7 & 7 & 4.5 & 1 & .6 & - & - & 4.31 & .58 \\
\hline $\begin{array}{l}\text { 18. Okuduğum } \\
\text { cümledeki anlamını } \\
\text { bilmediğim }\end{array}$ & 61 & 39.1 & 83 & 53.2 & 11 & 7.1 & 1 & .6 & - & - & 4.30 & .62 \\
\hline
\end{tabular}


Uşak Üniversitesi Sosyal Bilimler Dergisi

$2013,6 / 4$

M. KURUDAYIOĞLU, G. ÇELIKK

\begin{tabular}{|c|c|c|c|c|c|c|c|c|c|c|c|c|}
\hline $\begin{array}{l}\text { kelimelerin anlamın } \\
\text { bağlamdan } \\
\text { çıarabilirim }\end{array}$ & & & & & & & & & & & & \\
\hline $\begin{array}{l}\text { 19. Okunan } \\
\text { kelimeleri doğru } \\
\text { telaffuz edebilirim. }\end{array}$ & 62 & 39.7 & 75 & 48.1 & 17 & 10.9 & - & - & 2 & 1.3 & 4.25 & .75 \\
\hline $\begin{array}{l}\text { 20. Dikkatimi } \\
\text { okuduklarıma } \\
\text { yoğunlaştıramam. }\end{array}$ & 60 & 38.5 & 80 & 51.3 & 16 & 10.3 & - & - & - & - & 4.28 & .64 \\
\hline $\begin{array}{l}\text { 21. Ön bilgilerimi } \\
\text { kullanarak } \\
\text { okuduğumu } \\
\text { anlamlandırabilirim. }\end{array}$ & 61 & 39.1 & 85 & 54.5 & 8 & 5.1 & 1 & .6 & 1 & .6 & 4.30 & .65 \\
\hline $\begin{array}{l}\text { 22. Okuduğumu } \\
\text { anlamada görsellere } \\
\text { dikkat ederim. }\end{array}$ & 88 & 56.4 & 63 & 40.4 & 3 & 1.9 & 1 & .6 & 1 & .6 & 4.51 & .63 \\
\hline
\end{tabular}

Tablo 2'de, Türkçe öğretmeni adaylarının okumaya ilişkin özyeterlik algılarına ait bulgular görülmektedir. Türkçe öğretmeni adaylarının verdikleri cevaplar içresinde en yüksek düzeydeki görüşleri; "Kitap okumanın yararlı olduğunu düşünüyorum."dur. $(\bar{X}=4.69)$. Okuduğunu anlamada görsellere dikkat etme $(\bar{X}=4.51)$, okuduklarından çıkarımlar yapabilme $(\bar{X}=4.46)$, türüne göre okuma metni seçebilme ve okuduğu metinlerin türünü belirleyebilme $(\bar{X}=4.41)$ konularında öğretmenler kendilerini yeterli hissetmektedirler. Okuma alışkanlığını kazanmanın önemi konusunda duyarlı olma ( $\bar{X}=4.37)$, okuduklarındaki öznel ve nesnel yargıları ayırt edebilme $(\bar{X}=4.35)$ konusunda kısmen yeterli olduklarını düşünmektedirler. Okuma türleri konusunda yeterli bilgiye sahip olabilme ( $\bar{X}=4.08$ ), iyi bir okur olma $(\bar{X}=3.97)$, konularında öğretmen adayları kendilerini diğerlerine göre daha az yeterli görmektedirler.

Gazi Üniversitesi Sınıf Öğretmenliği ve Türkçe Eğitimi Bölümleri'nde okuyan öğretmen adaylarıyla yapılan bir araştırmanın sonuçlarına göre; öğretmen adaylarının yüzde 86,2'si (50) bir şeyler öğrenmek için okurken bir sorunla karşılaştıkları zaman sebebin genellikle kontrol edilebilir değişkenler olduğunu ifade etmişlerdir. Bu sebeplere örnek olarak ise, "metinde geçen kelime kadrosuna ve terimlere aşina olmama, metin yapısının bozuk olması, yorgun olma ve çevresel problemler" verilmiştir. 
Sekiz öğretmen adayı ise (\% 13,8) başarısızlıkla karşılaştıkları zaman nedenin genel olarak kontrol edemedikleri değişkenlerden kaynaklandığını belirtmişlerdir. Buna örnek bir ifadede ise öğretmen adayları düşüncelerini şöyle ifade etmişledir: "Genellikle okumada odaklanma güçlü̆̆̈̈ yaşıyorum, çoğunlukla başarısızlı̆̆ımın sebebi bu oluyor." (K7) ve "Okuyarak öğrenmede nadiren de olsa sorun yaşadığım oluyor, o zamanlarda başarısız oluyor ve bir arkadaşımdan bana konuyu anlatmasını istiyorum." (K23) (Uyar, Ateş ve Yildırım, 2012).

Öğretmen adaylarında uygulamış olduğumuz ankette 2 madde olumsuz yargı içermektedir. Dikkati okunanlara yoğunlaştıramama ( $\bar{X}=4.28$ ) konusunda öğretmen adayları bu görüşe katılmadıklarını ifade etmişlerdir. Bununla birlikte kitap okumanın zaman kaybı olduğunu düşünme ( $\bar{X}=4.73$ ) konusuna da aynı şekilde katılan öğretmen adayı sayısı düşüktür. Bu durum öğretmen adaylarının kitap okumanın gereksiz bir etkinlik değil, bilakis lüzumlu bir alışkanlık olduğu görüşüne yakın oldukları şeklinde yorumlanabilir.

Tablo 3. Türkçe Öğretmeni Adaylarının Okuma Eğitimi Özyeterlik Algıları

\begin{tabular}{|c|c|c|c|c|c|c|c|c|c|c|c|c|}
\hline & \multicolumn{2}{|c|}{ 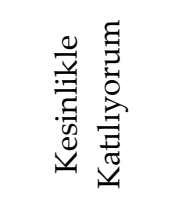 } & \multicolumn{2}{|c|}{ 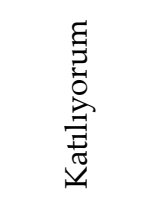 } & \multicolumn{2}{|c|}{ 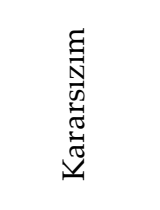 } & \multicolumn{2}{|c|}{ 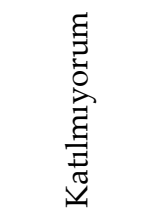 } & \multicolumn{2}{|c|}{ 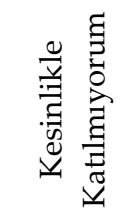 } & \multirow[t]{2}{*}{$\bar{X}$} & \multirow[t]{2}{*}{$S$} \\
\hline & f & $\%$ & $\mathrm{f}$ & $\%$ & $\mathbf{f}$ & $\%$ & $\mathbf{f}$ & $\%$ & $\mathrm{f}$ & $\%$ & & \\
\hline $\begin{array}{l}\text { 1.Türkçe } \\
\text { Programı'n } \\
\text { da yer alan } \\
\text { okuma } \\
\text { eğitimi } \\
\text { konusunda } \\
\text { yeterli } \\
\text { bilgiye } \\
\text { sahibim. }\end{array}$ & 28 & 17,9 & 86 & 55,1 & 34 & 21,8 & 7 & 4.5 & 1 & .6 & 3.85 & .78 \\
\hline $\begin{array}{l}\text { 2. Aldığım } \\
\text { eğitim } \\
\text { öğrencilere }\end{array}$ & 33 & 21.2 & 90 & 57.7 & 21 & 13.5 & 11 & 7.1 & 1 & .6 & 3.91 & .82 \\
\hline
\end{tabular}


Uşak Üniversitesi Sosyal Bilimler Dergisi

$2013,6 / 4$

M. KURUDAYIOĞLU, G. ÇELIKK

\begin{tabular}{|c|c|c|c|c|c|c|c|c|c|c|c|c|}
\hline $\begin{array}{l}\text { kitap } \\
\text { okuma } \\
\text { becerisini } \\
\text { kazandırabi } \\
\text { lecek } \\
\text { niteliktedir. }\end{array}$ & & & & & & & & & & & & \\
\hline $\begin{array}{l}3 . \\
\text { Okumanın } \\
\text { önemini } \\
\text { öğrencileri } \\
\text { min } \\
\text { kavramasını } \\
\text { sağlayabiliri } \\
\text { m. }\end{array}$ & 50 & 32.1 & 94 & 60.3 & 11 & 7.1 & 1 & .6 & - & - & 4.23 & .60 \\
\hline $\begin{array}{l}. \\
\text { Öğrencileri } \\
\text { min boş } \\
\text { zamanlarını } \\
\text { kitap } \\
\text { okuyarak } \\
\text { değerlendir } \\
\text { mesi için } \\
\text { onlara yol } \\
\text { gösterebiliri } \\
\text { m. }\end{array}$ & 57 & 36.5 & 87 & 55.8 & 11 & 7.1 & 1 & .6 & - & - & 4.28 & .62 \\
\hline $\begin{array}{l}5 . \\
\text { Öğrencileri } \\
\text { min } \\
\text { metinlerara } \\
\text { sı okuma } \\
\text { becerisini } \\
\text { kazanmaları } \\
\text { nı } \\
\text { sağlayabiliri } \\
\text { m. }\end{array}$ & 35 & 22.4 & 96 & 61.5 & 25 & 16.0 & - & - & - & - & 4.06 & .61 \\
\hline $\begin{array}{l}6 . \\
\text { Öğrencileri } \\
\text { min kitap } \\
\text { okurken } \\
\text { seçici } \\
\text { olmalarını } \\
\text { sağlayabiliri } \\
\text { m. }\end{array}$ & 47 & 30.1 & 86 & 55.1 & 22 & 14.1 & 1 & .6 & - & - & 4.14 & .67 \\
\hline
\end{tabular}


Uşak Üniversitesi Sosyal Bilimler Dergisi

$2013,6 / 4$

M. KURUDAYIOĞLU, G. ÇELIKK

\begin{tabular}{|c|c|c|c|c|c|c|c|c|c|c|c|c|}
\hline $\begin{array}{l}\text { 7. Kitapların } \\
\text { özenle } \\
\text { kullanılması } \\
\mathrm{n} \text { ı } \\
\text { sağlayabiliri } \\
\text { m. }\end{array}$ & 55 & 35.3 & 85 & 54.5 & 13 & 8.3 & 3 & 1.9 & - & - & 4.23 & .68 \\
\hline $\begin{array}{l}\text { 8. Yabanci } \\
\text { klasikleri } \\
\text { öğrencileri } \\
\text { me } \\
\text { tanitabilirim }\end{array}$ & 45 & 28.8 & 71 & 45.5 & 36 & 23.1 & 3 & 1.9 & 1 & .6 & 4.00 & .81 \\
\hline $\begin{array}{l}\text { 9. Sınıf } \\
\text { kitaplığ } \\
\text { oluşturabilir } \\
\text { im. }\end{array}$ & 69 & 44.2 & 75 & 48.1 & 10 & 6.4 & 2 & 13 & - & - & 4.35 & .66 \\
\hline $\begin{array}{l}\text { 10. Öğrenci } \\
\text { seviyesine } \\
\text { uygun } \\
\text { okuma } \\
\text { metni } \\
\text { seçebilirim. }\end{array}$ & 55 & 35.3 & 82 & 52.6 & 19 & 12.2 & - & - & - & - & 4.23 & .65 \\
\hline $\begin{array}{l}\text { 11. Okuma } \\
\text { çalışmaların } \\
\text { in ardından } \\
\text { öğrencileri } \\
\text { me } \\
\text { analiz,sente } \\
\text { z ve } \\
\text { yorumlama } \\
\text { becerileriyle } \\
\text { ilgili } \\
\text { çalışmalar } \\
\text { yaptırabiliri } \\
\text { m. }\end{array}$ & 44 & 28.2 & 94 & 60.3 & 15 & 9.6 & 1 & .6 & 2 & 1.3 & 4.13 & .71 \\
\hline $\begin{array}{l}\mathbf{1 2 .} \\
\text { Öğrencileri } \\
\text { min } \\
\text { okudukları } \\
\text { metinlerin } \\
\text { türlerini } \\
\text { ayırt } \\
\text { etmelerini } \\
\text { sağlayabiliri }\end{array}$ & 49 & 31.4 & 92 & 59.0 & 14 & 9.0 & 1 & .6 & - & - & 4.21 & .62 \\
\hline
\end{tabular}


Uşak Üniversitesi Sosyal Bilimler Dergisi

$2013,6 / 4$

M. KURUDAYIOĞLU, G. ÇELIKK

$\mathrm{m}$.

\begin{tabular}{|c|c|c|c|c|c|c|c|c|c|c|c|c|}
\hline $\begin{array}{l}\text { 13.Öğrencil } \\
\text { erimin } \\
\text { okudukları } \\
\text { kitaplar } \\
\text { hakkında } \\
\text { yapıcı } \\
\text { tartışmalar } \\
\text { yapabilmele } \\
\text { rini } \\
\text { sağlayabiliri } \\
\text { m. }\end{array}$ & 42 & 26.2 & 87 & 55.8 & 26 & 16.7 & - & - & 1 & .6 & 4.08 & .69 \\
\hline $\begin{array}{l}\text { 14. Okuma } \\
\text { eğitiminin } \\
\text { amaç ve } \\
\text { kazanımları } \\
\text { na yönelik } \\
\text { olarak } \\
\text { etkinlik } \\
\text { tasarlayabili } \\
\text { rim. }\end{array}$ & 65 & 41.7 & 76 & 48.7 & 13 & 8.3 & 2 & 1.3 & - & - & 4.30 & .67 \\
\hline $\begin{array}{l}\text { 15. Etkinliğe } \\
\text { uygun } \\
\text { yöntem } \\
\text { seçebilirim. }\end{array}$ & 66 & 42.3 & 73 & 46.8 & 16 & 10.3 & 1 & .6 & - & - & 4.30 & .67 \\
\hline $\begin{array}{l}\text { 16. Etkinliğe } \\
\text { uygun araç } \\
\text { gereç } \\
\text { seçebilirim. }\end{array}$ & 77 & 49.4 & 65 & 41.7 & 13 & 8.3 & 1 & .6 & - & - & 4.39 & .66 \\
\hline $\begin{array}{l}\text { 17. Etkinlik } \\
\text { planı } \\
\text { hazırlayabil } \\
\text { irim. }\end{array}$ & 76 & 48.7 & 69 & 44.2 & 11 & 7.1 & - & - & - & - & 4.41 & .62 \\
\hline $\begin{array}{l}\text { 18. Etkinliği } \\
\text { uygulayabil } \\
\text { irim. }\end{array}$ & 78 & 50.0 & 67 & 42.9 & 11 & 7.1 & - & - & - & - & 4.42 & .62 \\
\hline $\begin{array}{l}\text { 19. Okuma } \\
\text { eğitimine } \\
\text { yönelik } \\
\text { etkinliklerin } \\
\text { ölçme } \\
\text { değerlendir }\end{array}$ & 65 & 41.7 & 73 & 46.8 & 17 & 10.9 & 1 & .6 & - & - & 4.29 & .68 \\
\hline
\end{tabular}


Uşak Üniversitesi Sosyal Bilimler Dergisi

$2013,6 / 4$

M. KURUDAYIOĞLU, G. ÇELIKK

mesini

yapabilirim.

20.

Öğrencileri

min okuma

kurallarını

uygulaması

$\begin{array}{lllll}52 & 33.3 & 85 & 54.5 & 18\end{array}$

11.51

4.20

.65

n1

sağlayabiliri

m.

Noktalama

işaretlerine

dikkat

edilerek

$61 \quad 39$

39.1

$78 \quad 50.0$

16

10.31

.6

$4.27 \quad .66$

okunmasinı

sağlayabiliri

$\mathrm{m}$.

22.

Öğrencileri

$\min$

okudukları

metni

anlamasını

55

35.3

ve

çözümlemes

ini

sağlayabiliri

$\mathrm{m}$.

23.

Öğrencileri

$\min$

okudukları

metinleri dil

ve anlatım

$\begin{array}{lllllll}51 & 32.7 & 87 & 55.8 & 15 & 9.6 & 3\end{array}$

1.9

.68

yönünden

değerlendir

melerini

sağlayabiliri

$\mathrm{m}$.

24.

Öğrencileri

min

$\begin{array}{lllll}57 & 36.5 & 86 & 55.1 & 13\end{array}$

8.3

4.28

.60

okudukları 
Uşak Üniversitesi Sosyal Bilimler Dergisi

$2013,6 / 4$

M. KURUDAYIOĞLU, G. ÇELIKK

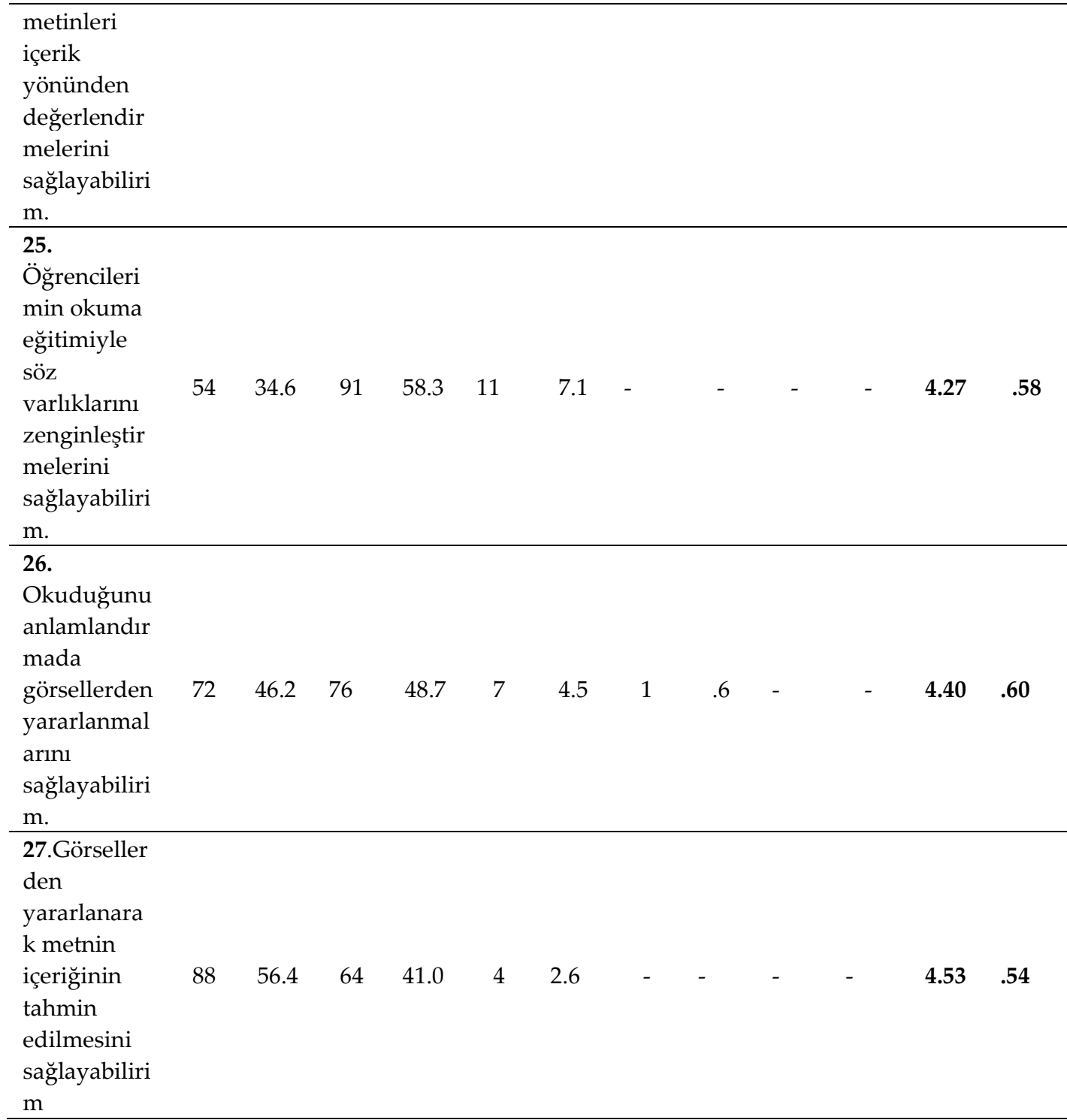

Tablo 3'de, Türkçe öğretmeni adaylarının okuma eğitimine ilişkin algılarına ait bulgular görülmektedir. Türkçe öğretmeni adaylarının verdikleri cevaplar içeresinde en yüksek düzeydeki görüşleri; görsellerden yararlanarak metnin içeriğinin tahmin edilmesini sağlayabilme ( $\bar{X}=4.53)$ ve etkinliği uygulayabilme $\quad(\bar{X}=4.42), \quad$ konularındadır. Okuduğunu anlamlandırmada görsellerden yararlanmalarını sağlayabilme $(\bar{X}=4.40)$, 
etkinliğe uygun araç gereç seçebilme $(\bar{X}=4.39)$, sınıf kitaplığı oluşturabilme ( $\bar{X}=4.35$ ) konularında öğretmen adayları kısmen yeterli olduklarını düşünmektedirler.

2012 yılında Çanakkale Onsekiz Mart Üniversitesi'nde Sınıf Öğretmeni adaylarının kitap okuma alışkanlığının değerlendirilmesiyle ilgili olan bir araştırmanın sonuçlarına göre; öğretmen adaylarından 5 kişi bir yılda hiç kitap okumadığını ifade etmiştir. 51 kişi 12 ve üzeri sayıda kitap okuduğunu belirtmiştir. Katılımcıların \% 80'i ise bir yılda 1-12 arası kitap okumaktadır. Öğretmen adaylarının okumayı tercih ettikleri kitaplar arasında ilk sırada aşk-sevgi konulu kitapların olduğu görülmektedir. Daha sonra ise; macera-bilim kurgu, kişisel gelişim ve dini kitapları okudukları görülmektedir ( Arı ve Demir, 2012).

Öğrencilerin okudukları kitaplar hakkında yapıcı tartışmalar yapabilmelerini sağlayabilme $(\bar{X}=4.08)$, öğrencilerin metinlerarası okuma becerisini kazanmalarını sağlayabilme $(\bar{X}=4.06)$, alınan eğitimin öğrencilere kitap okuma becerisini kazandırabilecek nitelikte olması $(\bar{X}=3.91)$, Türkçe Dersi Öğretim Programı'nda (MEB, 2006) yer alan okuma eğitimi konusunda yeterli bilgiye sahip olma $(\bar{X}=3.85)$ konularında öğretmen adayları kendilerini daha az yeterli görmektedirler.

Tablo 4: Türkçe Öğretmeni Adaylarının Cinsiyetleri ile Okuma Becerisi Özyeterlik Algıları Arasındaki İlişki

\begin{tabular}{cccccccc}
\hline & Cinsiyet & $\mathbf{N}$ & $\bar{X}$ & $\mathbf{S}$ & $\mathbf{s d}$ & $\mathbf{t}$ & $\mathbf{p}$ \\
\hline $\begin{array}{c}\text { Yeterlilik } \\
\text { Düzeyi }\end{array}$ & Kadın & 85 & 4.15 & .38 & 154 & .84 & .39 \\
& Erkek & 71 & 4.10 & .37 & & & \\
\hline
\end{tabular}

Tablo 4 incelendiğinde, cinsiyete bağlı olarak Türkçe öğretmeni adaylarının okuma becerisi özyeterliği algıları arasında farklılık olmadığı görülmektedir, $\mathrm{t}(154)=.84, \mathrm{p}>.05$. Bu sonuçlara göre; kadın öğretmen adaylarının okuma becerisi özyeterliği konusundaki yeterlilik düzeylerine ilişkin algı puanlarının ortalaması $(\bar{X}=4.15)^{\prime}$ dir. Erkek öğretmen adaylarının okuma eğitimi konusundaki yeterlilik düzeylerine ilişkin alg1 
puanlarının ortalaması ( $\bar{X}=4.10$ )'dur. Erkek ve kadın öğretmen adaylarının ortalamalarının birbirine yakın olduğu görülmektedir. Buna göre; erkek ve kadın öğretmen adaylarının okuma becerilerinin yeterliliği konusunda benzer özyeterlik algılarına sahip oldukları görülmektedir.

Okuma konusunda yapılan bazı araştırmalarda ise cinsiyet değişkenini bazı farklılıklar ortaya koyduğu görülmektedir. Filiz (2004) yapmış olduğu araştırmada Beden Eğitimi öğrencileri arasında kadınların $\% 87,2^{\prime}$ sinin, erkeklerin ise \% 77,4'ünün kitap okuduğunu belirlemiştir. Görüldüğü gibi kadın öğretmen adayları erkeklere göre okumaya karşı daha ilgilidir. Benzer bir sonuç Özbay, Bağcı ve Uyar (2008)'ın Türkçe öğretmeni adaylarına uyguladıkları bir çalışmanın sonucunda da görülmektedir. Bu araştırmanın sonuçlarına göre; sevgi, alışkanlık, gereklilik ve istek alt boyutlarına ilişkin tutumlarında kadın öğretmen adaylarının kitap okumaya ilişkin tutumlarının erkek öğretmen adaylarına göre daha olumlu olduğu tespit edilmiştir. Balıkesir Üniversitesi'nde Fen Bilgisi Eğitimi, Türkçe Eğitimi, Sosyal Bilgiler Öğretmenliği gibi farklı bölümlerde yapılmış olan bir araştırmanın sonuçlarına göre de; okuma stratejilerini kullanma düzeyleriyle cinsiyet arasındaki ilişki kız öğrenciler lehine anlamlı bir farklılık göstermiştir (Topuzkanamış ve Maltepe, 2010).

Tablo 5. Türkçe Öğretmeni Adaylarının Cinsiyetleri İle Okuma Eğitimi Özyeterlik Algıları Arasındaki İlişki

\begin{tabular}{cccccccc}
\hline & Cinsiyet & $\mathbf{N}$ & $\bar{X}$ & S & sd & $\mathbf{t}$ & $\mathbf{p}$ \\
\hline $\begin{array}{c}\text { Yeterlilik } \\
\text { Düzeyi }\end{array}$ & Kadın & 85 & 4.26 & .39 & & & \\
& Erkek & 71 & 4.20 & .37 & & & .37 \\
\hline
\end{tabular}

Tablo 5 incelendiğinde, Türkçe öğretmeni adaylarının okuma eğitimi algıları cinsiyete göre anlamlı bir farklılık göstermemektedir, $\mathrm{t}(154)=.89, \mathrm{p}>.05$. Kadın öğretmen adaylarının okuma eğitimi konusundaki yeterlilik düzeylerine ilişkin algı puanlarının ortalaması $(\bar{X}=4.26)^{\prime} \mathrm{d}$ r. Erkek öğretmen adaylarının okuma eğitimi konusundaki yeterlilik düzeylerine ilişkin algı puanlarının ortalaması $(\bar{X}=4.20)^{\prime}$ dir. Erkek ve kadın öğretmen adaylarının ortalamalarının birbirine yakın olduğu görülmektedir. Bu sonuca göre; erkek ve kadın öğretmen adaylarının okuma eğitimi verebilme konusunda benzer yeterlik algılarına sahip oldukları görülmektedir. 
Ankara Üniversitesi'nde yapılan ve üniversite öğrencilerinin okuma alışkanlığını tespit etmeyi amaçlayan bir araştırmanın sonuçlarına göre kadın öğrencilerin erkeklere oranla okuma etkinliğine daha fazla süre ayırdıkları görülmektedir. Bununla birlikte öğrencilerin önemli bir bölümü düşük okuma kültürüne sahiptir. Bir yıl boyunca hiç kitap okumayan üniversite öğrencilerinin bulunması da şaşırtıcı bir durumdur. Okumamaya etken olarak ekonomik durumlarını ileri sürmüş olsalar da, maddi durumu düşük öğrencilerin üst düzey sosyo-ekonomik düzeyde olan öğrencilerle eşit okuma oranına sahip oldukları görülmüştür (Odabaş, Odabaş ve Polat, 2008).

Avrupa Eğitim Sitemlerinde 15 yaşındaki erkeklerin kızlardan yaklaşık olarak iki kat fazla oranda okumada zorlandıkları tespit edilmiştir. PISA'nın yapmış olduğu araştırmanın sonuçlarına göre; erkek ve kadın öğrenciler arasında okuma oranındaki en büyük fark Finlandiya'da gözlenmiştir. Erkekler kadınlara oranla 4 kat daha fazla okuma zorluğu çekmektedir. Bu durum AB-27 ülkelerine göre, Finlandiya'da daha az öğrencinin başarısının düşük olarak sınıflandırılmasından doğmuş olabilir. PISA 2000 ve PISA 2009 cinsiyet sonuçları karşılaştırıldığında Fransa, Portekiz, Romanya ve İsveç'te önemli ölçüde yüksek ortalama farkları tespit edilmiştir (Avrupa Komisyonu, 2011).

Tablo 6: Türkçe Öğretmeni Adaylarını Sınıf Düzeyleri İle Okuma Becerisi Özyeterlik Alglları Arasındaki İlişki

\begin{tabular}{cccccccc} 
& Sinıf & $\mathbf{N}$ & $\bar{X}$ & S & sd & $\mathbf{t}$ & $\mathbf{p}^{*}$ \\
$\begin{array}{ccccc}\text { Yeterlilik } \\
\text { Dïzeyi }\end{array}$ & 3. Sinıf & 106 & 4.04 & .29 & & & \\
& 4. Sinıf & 50 & 4.30 & .46 & & $-4,1$ & .00 \\
\hline
\end{tabular}

$$
{ }^{*} \mathrm{p}<.05
$$

Tablo 6 incelendiğinde, sınıf düzeyine bağlı olarak Türkçe öğretmeni adaylarının okuma becerisi özyeterliği algıları arasında farklılık olup olmadığına ilişkin bulgular görülmektedir. Bu sonuçlara göre; öğretmen adaylarının okuma becerisi özyeterliği konusundaki algıları ile sınıf düzeyleri arasında anlamlı bir farklılık görülmektedir, $\mathrm{t}(154)=-4,1, \mathrm{p}<.05 .4$. sınıfta okuyan öğretmen adaylarının okuma eğitimi konusundaki yeterlilik 
düzeylerine ilişkin tutumlarının ( $\bar{X}=4.30)$, 3. sınıfa devam eden öğretmen adaylarının tutumlarına ( $\bar{X}=4.04$ ) göre daha olumlu olduğu görülmektedir.

Türkçe öğretmeni adaylarının aldıkları eğitim sonunda okuma eğitiminin önemi konusunda daha duyarlı olmaya başladıkları görülmektedir. Son sınıfta okuma eğitimine karşı olan tutumlarının daha olumlu yönde olması, almış oldukları eğitime bağlanabilir.

Tablo 7: Türkçe Öğretmeni Adaylarını Sınıf Düzeyleri İle Okuma Ĕ̆itimi Özyeterlik Algıları Arasındaki İlişki

\begin{tabular}{cccccccc}
\hline & Sinıf & $\mathbf{N}$ & $\bar{X}$ & $\mathbf{S}$ & $\mathbf{s d}$ & $\mathbf{t}$ & $\mathbf{p}$ \\
\hline $\begin{array}{c}\text { Yeterlilik } \\
\text { Düzeyi }\end{array}$ & 3. Sinıf & 106 & 4.24 & .32 & & & \\
& 4. Sinıf & 50 & 4.21 & .49 & & & .63 \\
\hline
\end{tabular}

Tablo 7 incelendiğinde, sınıf düzeyine bağlı olarak Türkçe öğretmeni adaylarının okuma eğitimi tutumları sınıf düzeyine göre anlamlı bir farklılık göstermemektedir, $\mathrm{t}(154)=.47, \mathrm{p}>.05$. Bu sonuçlara göre; 3 . sınıfa devam eden öğretmen adaylarının okuma eğitimi konusundaki yeterlilik düzeylerine ilişkin tutumları ( $\bar{X}=4.24$ ) ile 4. sınıfta okuyan öğretmen adaylarının okuma eğitimi konusundaki yeterlilik düzeylerine ilişkin tutumlarının $(\bar{X}=4.21)$ birbirlerine yakın olduğu görülmektedir. 3. sınıfta ve 4. sınıfta okuyan öğretmen adaylarının ortalamalarının birbirine yakın olduğu görülmektedir. Bu sonuca göre; 3. sınıfta ve 4. sınıfta okumakta olan öğretmen adaylarının okuma eğitimi verebilme konusunda benzer yeterlik algılarına sahip oldukları görülmektedir.

Tablo 8: Türkçe Öğretmeni Adaylarını Öğretim Şekli İle Okuma Becerisi Özyeterlik Algıları Arasındaki İlişki

\begin{tabular}{cccccccc}
\hline & Sınıf & $\mathbf{N}$ & $\bar{X}$ & $\mathbf{S}$ & $\mathbf{s d}$ & $\mathbf{t}$ & $\mathbf{p}^{*}$ \\
\hline $\begin{array}{c}\text { Yeterlilik } \\
\text { Düzeyi }\end{array}$ & Öğğretim & 79 & 4.06 & .35 & & & \\
& İkinci & 76 & 4.19 & .39 & & & \\
\hline
\end{tabular}


Öğretim

${ }^{*} \mathrm{p}<.05$

Tablo 8 incelendiğinde, öğretim şekline bağlı olarak Türkçe öğretmeni adaylarının okuma becerisi özyeterliği algıları arasında farklılık olup olmadığına ilişkin bulgular görülmektedir. Öğretmen adaylarının okuma becerisi özyeterlik algılarının devam ettikleri öğretim şekline göre anlamlı bir farklılık gösterdiği görülmektedir, $t(153)=-2,26, p<.05$. Normal öğretimde okumakta olan öğretmen adaylarının okuma becerisi özyeterliği konusundaki yeterlik düzeylerine ilişkin algı puanlarının ortalaması ( $\bar{X}=4.06)^{\prime}$ dır. İkinci öğretimde okuyanların ortalaması ise $(\bar{X}=4.19)^{\prime}$ dur. Bu sonuca göre; ikinci öğretimde okuyan öğretmen adaylarının okuma becerilerine yönelik özyeterlik algıları normal öğretimde okuyan öğretmen adaylarına göre daha olumludur.

Tablo 9: Türkçe Öğretmeni Adaylarının Öğretim Şekli İle Okuma Eğitimi Özyeterlik Algıları Arasındaki İlişki

\begin{tabular}{|c|c|c|c|c|c|c|c|}
\hline & Sinıf & $\mathbf{N}$ & $\bar{X}$ & $\mathrm{~S}$ & sd & $t$ & $\mathbf{p}^{*}$ \\
\hline \multirow{2}{*}{$\begin{array}{c}\text { Yeterlilik } \\
\text { Düzeyi }\end{array}$} & $\begin{array}{l}\text { Normal } \\
\text { Öğretim }\end{array}$ & 79 & 4.12 & .38 & \multirow{2}{*}{153} & \multirow{2}{*}{-3.68} & \multirow{2}{*}{.00} \\
\hline & $\begin{array}{l}\text { İkinci } \\
\text { Öğretim }\end{array}$ & 76 & 4.34 & .36 & & & \\
\hline
\end{tabular}

Öğretmen adaylarının okuma eğitimi algıları konusundaki yeterlilik algıları devam ettikleri öğretim şekline göre anlamlı bir farklılık göstermektedir, $\mathrm{t}(153)=-3.68, \mathrm{p}<.05$. Bu sonuçlara göre; normal öğretime devam eden öğretmen adaylarının okuma eğitimi algıları konusundaki yeterlik düzeylerine ilişkin algı puanlarının ortalaması $(\bar{X}=4.12)^{\prime}$ dir. İkinci öğretimde okuyan öğretmen adaylarının okuma eğitimi konusundaki yeterlik düzeylerine ilişkin algı puanlarının ortalaması $(\bar{X}=4.34)^{\prime}$ tür. Bu sonuca göre; ikinci öğretimde okuyan öğretmen adaylarının okuma becerilerine yönelik özyeterlik algıları normal öğretimde okuyan öğretmen adaylarına göre daha olumludur. 
Tablo 10: Türkçe Öğretmeni Adaylarının Mezun Olunan Lise İle Okuma Becerisi Özyeterlik Algılarn Arasındaki Illişki

\begin{tabular}{lcclll}
\hline $\begin{array}{l}\text { Varyans } \\
\text { Analizi }\end{array}$ & $\begin{array}{l}\text { Kareler } \\
\text { Toplamı }\end{array}$ & $\begin{array}{l}\text { Serbestlik } \\
\text { Derecesi }\end{array}$ & $\begin{array}{l}\text { Kareler } \\
\text { Ortalaması }\end{array}$ & $\begin{array}{l}\text { F } \\
\text { Değeri }\end{array}$ & $\begin{array}{l}\text { Önem } \\
\text { Düzeyi }\end{array}$ \\
\hline Gruplar Arası &, 164 & 4 &, 041 & & \\
Gruplar İçi & 21,817 & 151 &, 144 &, 284 & $\mathbf{. 8 8 8}$ \\
Toplam Kareler & 21,981 & 155 & & & \\
\hline
\end{tabular}

Tablo 10'da Türkçe öğretmeni adaylarının mezun olunan lise ile okuma becerisi özyeterliği algıları arasında farklılık olup olmadığına ilişkin bulgular yer almaktadır. Buna göre; Türkçe öğretmeni adaylarının mezun olunan lise ile okuma becerisi özyeterliği arasında anlamlı bir farklılık yoktur, F $(4,151)=, 284, p>.05$. Yabanc1 dil liselerinden mezun olan Türkçe öğretmeni adaylarının okuma becerisi yeterliği algı puanlarının ortalaması $(\bar{X}=4,17)^{\prime}$ dir ve en yüksek ortalamadır. Anadolu Lisesi mezunlarının ortalaması $(\bar{X}=4,12)$, Düz Lise mezunlarının ortalaması $(\bar{X}=4,11)$, Anadolu Öğretmen Lisesi mezunlarının ortalaması $(\bar{X}=4,10)$ ve diğer liselerden mezun olan öğretmen adaylarının ortalaması ise; $(\bar{X}=3,95)^{\prime}$ tir.

Çalışmamamıza benzer şekilde sonuca Uşak'ta yapılmış olan bir araştırmada da ulaşılmıştır. Bu araştırmanın sonuçlarına göre; farklı bölümlerde okuyan öğretmen adaylarının ilköğretim ve ortaöğretimi tamamladıkları yer okuma alışkanlıklarını doğrudan etkilememektedir. Aynı şekilde yurt, pansiyon, aile yanı ya da yalnız kalmaları da okuma alışkanlıkları üzerinde etkili değildir. Yüksek gelire sahip öğretmen adaylarıyla, düşük gelire sahip öğretmen adayları arasında da aynı şekilde anlamlı bir farklılık olmadığı görülmüştür (Batur, Gülveren ve Bek, 2010). 
Tablo 11: Türkçe Öğretmeni Adaylarmnn Mezun Olunan Lise İle Okuma Eğitimi Özyeterlik Algıları Arasındaki İlişki

\begin{tabular}{lcclll}
\hline Varyans & $\begin{array}{l}\text { Kareler } \\
\text { Toplamı }\end{array}$ & $\begin{array}{l}\text { Serbestlik } \\
\text { Derecesi }\end{array}$ & $\begin{array}{l}\text { Kareler } \\
\text { Ortalaması }\end{array}$ & $\begin{array}{l}\text { F } \\
\text { Değeri }\end{array}$ & $\begin{array}{c}\text { Önem } \\
\text { Düzeyi }\end{array}$ \\
\hline Gruplar Arası &, 267 & 4 &, 067 & & \\
Gruplar İçi & 23,066 & 151 &, 153 &, 437 & $\mathbf{. 7 8 2}$ \\
Toplam Kareler & 23,332 & 155 & & & \\
\hline
\end{tabular}

Tablo 11'e göre; Türkçe öğretmeni adaylarının okuma eğitimi algıları ile mezun oldukları lise türü arasında anlamlı bir farklılık görülmediği şeklinde yorum yapılabilir, $\mathrm{F}(4,151)=, 437, \mathrm{p}>.05$. Yabancı dil liselerinden mezun olanların okuma eğitimi algı puanlarının ortalaması $(\bar{X}=4,30)^{\prime}$ dur ve en yüksek ortalamadır. Anadolu Lisesi mezunlarının okuma eğitimi alg1 puanlarının ortalaması $(\bar{X}=4,24)$ iken, Anadolu Öğretmen Lisesi mezunlarının ortalaması ( $\bar{X}=4,20)$, düz lise mezunlarının ortalaması $(\bar{X}=4,19)$, ve diğer liselerden mezun olanların ortalaması ise $(\bar{X}=4,27)^{\prime}$ dir.

\section{Sonuç ve Tartışma}

Okuma alışkanlığını kazanmak insanın yepyeni bir dünyaya adım atması anlamına gelmektedir. Okumak insanın özgürlüğüdür. Bu alışkanlığın kazanılmasında Türkçe derslerinin ve Türkçe öğretmenlerinin etkisi büyük olmaktadır. Okuma becerisini kazandırma konusunda kendisini yetkin gören öğretmenler daha başarılı olabilecektir.

Bu çalışmada Türkçe öğretmeni adaylarının sahip oldukları okuma becerisi ve bunu öğrencilerine kazandırabilme konusundaki yeterlilik düzeylerine ilişkin özyeterlik algılarını belirlemek amaçlanmıştır. Anket sonuçlarına göre öğretmen adayları; "Kitap okumanın yararlı olduğunu düşünüyorum." konusunda kendilerini yeterli görmektedir. Görsellerden yararlanarak metnin içeriğinin tahmin edilmesini sağlayabilme, okuduğunu 
anlamada görsellere dikkat etme, okuduklarından çıkarımlar yapabilme, etkinliği uygulayabilme, türüne göre okuma metni seçebilme konularında da öğretmen adayları kendilerini yeterli hissetmektedirler. Okuduğunu anlamlandırmada görsellerden yararlanmalarını sağlayabilme, etkinliğe uygun araç gereç seçebilme, okuma alışkanlığını kazanmanın önemi konusunda duyarlı olma, sınıf kitaplığı oluşturabilme, okuduklarındaki öznel ve nesnel yargıları ayırt edebilme konularında ise kendilerini kısmen yeterli görmektedirler. Dikkati okunanlara yoğunlaştıramama konusunda öğretmen adayları bu görüşe katılmadıklarını ifade etmişlerdir. Bununla birlikte kitap okumanın zaman kaybı olduğunu düşünme konusuna da aynı şekilde katılan öğretmen adayı sayısı düşüktür.

Yapılan analiz sonuçlarına göre; Türkçe öğretmeni adaylarının cinsiyete göre okuma eğitimi özyeterlik algıları arasında anlamlı bir farklılık yoktur. Aynı şekilde okuma yeterliği ile cinsiyet arasında anlamlı bir farklılık yoktur. Sınıf düzeyine bağlı olarak Türkçe öğretmeni adaylarının okuma eğitimi özyeterlik algıları anlamlı bir farklılık göstermemektedir. Öğretmen adaylarının okuma becerisi özyeterliği konusundaki algıları ile sınıf düzeyleri arasında anlamlı bir farklılık görülmektedir. Bunun nedeni; 4 . sınıfa geçen öğretmen adaylarının okuma yeterliliklerini geliştirmiş olmaları şeklinde açıklanabilir.

Öğretmen adaylarının okuma eğitimi algıları konusundaki yeterlilik algıları devam ettikleri öğretim şekline göre anlamlı bir farklılık göstermektedir. İkinci öğretimde okuyan öğretmen adaylarının okuma eğitimi özyeterlik algıları daha yüksektir. Öğretmen adaylarının okuma becerisi özyeterlik algılarının devam ettikleri öğretim şekline göre anlamlı bir farklılık gösterdiği görülmektedir. Burada da ikinci öğretimde okuyanların okuma becerisi özyeterlilik algıları daha yüksek olarak belirlenmiştir. Bu durumun çeşitli nedenleri olabilir. Bu öğretim şeklinde okuyanlar bölümü isteyerek seçmiş olabilir. Kendilerini geliştirmeye açık olan öğrenciler çoğunlukta olabilir. Türkçe öğretmeni adaylarının okuma eğitimi algıları ile mezun oldukları lise türü arasında anlamlı bir farklılık görülmediği şeklinde yorum yapılabilir. Türkçe öğretmeni adaylarının mezun olunan lise ile okuma becerisi özyeterliği arasında anlamlı bir farklillk yoktur.

Yaptığımız araştırmanın sonuçlarına göre; okuduğunu anlamlandırmada görsellerden yararlanmalarını sağlayabilme, etkinliğe uygun araç gereç seçebilme, okuma alışkanlığını kazanmanın önemi 
konusunda duyarlı olma, sınıf kitaplığı oluşturabilme, okuduklarındaki öznel ve nesnel yargıları ayırt edebilme konularında öğretmen adaylarının kendilerini geliştirmeleri gerekmektedir. Görsel okuryazarlık ülkemizde son yıllarda önem verilen bir okuma alanıdır. Bu konuda öğretmen adaylarını kendilerini geliştirmek için yeni yaklaşımları takip etmek durumundadır. Zeren ve Arslan (2009)'ın da belirtmiş olduğu gibi; günümüzde yaşadığımız toplumda görsellerin büyük etkisiyle karşı karşıya bulunmaktayız. Görsel imgeleri doğru anlamlandırabilme, yorumlayabilme ve görsel çağrışımları çözümleyebilme yeterliğine sahip olmak son yıllarda bir ihtiyaç halini almıştır.

Sınıf kitaplı̆̆ı oluşturma bireysel özveri isteyen bir durumdur. Öğrencilerin yeni kitaplara ulaşmalarını sağlamak, maddi durumu iyi olmayan öğrencilere imkânlar oluşturmak ancak öğretmenlerin kendi çabalarıla ve istekleriyle daha iyi duruma getirilebilecek konulardır. Etkinlikler için araç-gereç hazırlama da okumaya ilgiyi arttıracaktır.

Okuma Türkçe dersinin temel becerilerindendir. $\mathrm{Bu}$ beceriyi kazandırabilmek için Türkçe Dersi Öğretim Programı'nda (MEB, 2006) farklı etkinliklere yer verilmekte, öğrencilerin okumayı sevmesi sağlanmaya çalışılmaktadır. Türkçe öğretmenleri okumayı sevmezse ve bu alışkanlığa sahip değillerse, kendi yetiştirecekleri öğrencilerine de bu sevgiyi kazandıramayacaklardır. Bu nedenle de üniversitelerde Türkçe Eğitimi bölümleri okuma eğitimine ilk ve öncelikli önemi göstermelidir. Okuyan toplum her çağda bir adım önde olacaktır.

\section{Kaynaklar}

Akyol, H. (2012). Programa Uygun Türkçe Öğretim Yöntemleri. Ankara: Pegem Akademi.

Arı, E. ve Demir, K. (2012). İlköğretim Bölümü Öğretmen Adaylarının Kitap Okuma Alışkanlıklarının Değerlendirilmesi, Ana Dili Eğitimi Dergisi, 1(1), 116-128.

Arıcı, A. F. (2008). Okuma Eğitimi. Ankara: Pegem Akademi. 
Avrupa Komisyonu (2011). Avrupa'da Okuma Eğitimi: Bağlam, Politika ve Uygulamalar, Eğitim, İşitsel Görsel Medya ve Kültür Yürütme Ajansi.

Aytaş, G. (2005). Okuma Eğitimi, Türk Eğitim Bilimleri Dergisi, C:3, S.4, 461470.

Bandura, A. (2006). Guide for Creating Self-efficacy Scales. In F. Pajares and T.C. Urdan (Eds.) Self-efficacy Beliefs of Adolescents Greenwich, Connecticut: Information Age Publication, 305-337.

Batur, Z., Gülveren, H. ve Bek H. (2010). Öğretmen Adaylarının Okuma Alışkanlıkları Üzerine Bir Araştırma: Uşsak Eğitim Fakültesi Örneği. Uşak Üniversitesi Sosyal Bilimler Dergisi, 3/1, 32-49.

Çetin, B. (2008). Marmara Üniversitesi Sınıf Öğretmeni Adaylarının Bilgisayarla İlgili Öz-yeterlik Algılarının İncelenmesi. D.Ü.Ziya Gökalp Eğitim Fakültesi Dergisi, 11,101-114.

Filiz, K. (2004).Gazi Üniversitesi Beden Eğitimi ve Spor Yüksekokulunda Okuyan Öğrencilerin Meslekle İlgili Okuma ve Araştırma Alışkanlıkları. Gazi Eğitim Fakültesi Dergisi, Cilt 24,Sayı 2, 231-242.

Gömleksiz, M. N. (2004). Kitap Okuma Alışkanlığına İlişkin Bir Tutum Ölçeğinin Geçerlik ve Güvenirliği, Furat Üniversitesi Sosyal Bilimler Dergisi, Cilt 14, Say1 2,185-195.

Güneş, F. (2012). Okuma ve Zihni Yönetme, Mustafa Kemal Üniversitesi Sosyal Bilimler Enstitüsü Dergisi, Cilt 9, Sayı 18, 1-15.

Karasar, N. (2007). Bilimsel Araştırma Yöntemi. İstanbul: Nobel Yayın Dağıtım.

Karatay, H. (2011). Okuma Eğitimi Kuram ve Uygulama. Ankara: Berikan Yayınevi.

Kurudayığlu, M. (2011). Zihinsel ve Fiziksel Bir Süreç Olarak Okuma, Gazi Eğitim Fakültesi Dergisi, Cilt 31,Sayı 1, 15-29. 
Kurulgan, M. ve Çekerol, G. S. (2008). Öğrencilerin okuma ve kütüphane kullanma alışkanlıkları üzerine bir araştırma, Anadolu Üniversitesi Sosyal Bilimler Dergisi, Cilt/Vol.:8-Sayı/No:2, 237-258.

Manguel, A. (2004). Okumanın Tarihi. İstanbul: Yapı Kredi Yayınları.

MEB (2006). Türkçe Dersi 6,7,8. Sınıflar Öğretim Programı. Ankara: Millî Eğitim Bakanlığı Talim ve Terbiye Kurulu Başkanlığı.

Odabaş, H., Odabaş Y. ve Polat C. (2008). Üniversite Öğrencilerinin Okuma Alışkanlığı: Ankara Üniversitesi Örneği, Bilgi Dünyası, 9(2), 431-465.

Özbay, M., Bağcl, H. ve Uyar, Y. (2008). Türkçe Öğretmeni Adaylarının Okuma Alışkanlığına Yönelik Tutumlarının Çeşitli Değişkenlere Göre Değerlendirilmesi, İnönü Üniversitesi Eğitim Fakültesi Dergisi, Cilt 9, Sayı 15,117-136.

Özbay, M. ve Özdemir, B. (2012). Okuduğunu Anlama Sürecinde Çıkarım Yapma Becerisinin İşlevi, Mustafa Kemal Üniversitesi Sosyal Bilimler Enstitüsü Dergisi, Cilt 9, Sayı 18, 17-28.

Şahin, A. (2010). Türkçe Öğretmeni Adaylarının Kütüphaneleri Kullanma Durumları, Turkish Studies, International Periodical For the Languages, Literature and History of Turkish or Turkic,Volume 5/4 Fall.

Temizkan, M. (2009). Metin Türlerine Göre Okuma Eğitimi. Ankara: Nobel Yayın Dağıtım.

Topuzkanamış,E. ve Maltepe S. (2010). Öğretmen Adaylarının Okuduğunu Anlama ve Okuma Stratejilerini Kullanma Düzeyleri, Türklük Bilimi Araştırmaları, Sayı 27, 655-677.

Uyar, Y., Ateş, S. ve Yıldırım, K. (2012). Öğretmen Adaylarının Okuduğunu Anlama Sürecinde Kullandıkları Öz Düzenlemeye Dayalı Öğrenme Becerileri, Mustafa Kemal Üniversitesi Sosyal Bilimler Enstitüsü Dergisi, Cilt 9, Sayı 18, 227-247.

Yılmaz, Z. A. (2006). Sınıf Öğretmeni Adaylarının Okuma Alışkanlığı, İlköğretim Online, 5(1), 1-6. http://ilkogretim-online.org.tr. 
Uşak Üniversitesi Sosyal Bilimler Dergisi

$2013,6 / 4$

M. KURUDAYIOĞLU, G. ÇELIK

Zeren, G. ve Arslan R. (2009). Bir Eğitim Süreci Olarak Görsel Okuryazarlık. TSA, Y1l 13, Sayı 3,43-52. 